\title{
Lysyl oxidase family members in urological tumorigenesis and fibrosis
}

\author{
Tao $\mathrm{Li}^{1,2}$, Changjing Wu${ }^{1}$, Liang Gao ${ }^{3}$, Feng Qin ${ }^{1}$, Qiang Wei ${ }^{2}$ and Jiuhong Yuan ${ }^{1,2}$ \\ ${ }^{1}$ The Andrology Laboratory, West China Hospital, Sichuan University, Chengdu, Sichuan, China \\ ${ }^{2}$ Department of Urology, West China Hospital, Sichuan University, Chengdu, Sichuan, China \\ ${ }^{3}$ Department of Urology, The Second Affiliated Hospital of Chongqing Medical University, Chongqing, China \\ Correspondence to: Jiuhong Yuan, email: jiuhongyuan2107@163.com \\ Keywords: lysyl oxidase; tumorigenesis; fibrosis; urological cancer; collagen
}

Received: September 29, $2017 \quad$ Accepted: March 11, $2018 \quad$ Published: April 13, 2018

Copyright: Li et al. This is an open-access article distributed under the terms of the Creative Commons Attribution License 3.0 (CC BY 3.0), which permits unrestricted use, distribution, and reproduction in any medium, provided the original author and source are credited.

\section{ABSTRACT}

Lysyl oxidase (LOX) is an extracellular copper-dependent monoamine oxidase that catalyzes crosslinking of soluble collagen and elastin into insoluble, mature fibers. Lysyl oxidase-like proteins (LOXL), LOX isozymes with partial structural homology, exhibit similar catalytic activities. This review summarizes recent findings describing the roles of LOX family members in urological cancers and fibrosis. LOX/ LOXL play key roles in extracellular matrix stability and integrity, which is essential for normal female pelvic floor function. LOX/LOXL inhibition may reverse kidney fibrosis and ischemic priapism. LOX and LOXL2 reportedly promote kidney carcinoma tumorigenesis, while LOX, LOXL1 and LOXL4 suppress bladder cancer growth. Multiple studies agree that the LOX propeptide may suppress tumor growth, but the role of LOX in prostate cancer remains controversial. Further studies are needed to clarify the exact effects and mechanism of LOX/LOXL on urological malignancies.

\section{LYSYL OXIDASE}

Lysyl oxidase (LOX) is a copper-dependent monoamine oxidase in the extracellular matrix (ECM) [1]. There are four LOX isozymes in humans that share partial structural homology with LOX, namely lysyl oxidaselike proteins $1-4$ (LOXL1/2/3/4), and the five members together form the lysyl oxidase family $[1,2]$. The four LOXLs share $85 \%, 58 \%, 65 \%$, and $62 \%$ homology with LOX, respectively [2], and the human LOX/LOXL genes are located on chromosomes $5,15,8,2$, and 10, $[1,2]$. LOX/LOXLs are expressed at different levels, and human LOX expression is low under normal conditions. While overall LOXL2/3/4 expression is low in adult rats, LOXL1 levels are higher than those of LOX [3]. The human LOX/ LOXL proteins also vary greatly in size; LOX has the shortest open reading frame, encoding 417 amino acids, while LOXL2 has the longest, with 774 amino acids $[2,3]$ (Table 1).
Both LOX and LOXL have catalytic activities. The C-terminus regions of the five family members share $95 \%$ homology, and are comprised of a highly conserved, 205-amino acid structural domain that is essential for bioactivity [3]. This catalytic region includes four conserved histidine residues to coordinate copper binding and a cofactor lysine tyrosine quinone (LTQ) formed by conserved lysine and tyrosine residues [3]. The $\mathrm{NH}_{2}$-terminal sequence is unique to each family member, and may determine cellular localization and/or mediate protein-protein interactions [3].

LOX/LOXL expression is highly tissue-specific. LOX is most commonly expressed in the heart and is also highly expressed in lung, kidney, testis, uterus, and placenta. LOXL1 is abundant in heart, lung, kidney, pancreas, and muscle. LOXL2 is abundant in the early stages of fetal heart development, and is highly expressed in the uterus, placenta, and other organs [2-4]. However, these are lowly expressed in brain and liver [4]. LOX3 is 
Table 1: Lysyl oxidase family member

\begin{tabular}{lccccc}
\hline Member & $\begin{array}{c}\text { Human } \\
\text { chromosome }\end{array}$ & $\begin{array}{c}\text { mRNA } \\
\text { size }\end{array}$ & $\begin{array}{c}\text { Protein } \\
\text { size }\end{array}$ & $\begin{array}{c}\text { Similarity to } \\
\text { LOX }\end{array}$ & $\begin{array}{c}\text { Highest mRNA levels in adult tissue } \\
\text { distribution }\end{array}$ \\
\hline LOX & 5 & $4.8 \mathrm{~kb}$ & $417 \mathrm{AA}$ & - & $\begin{array}{c}\text { Heart, lung, kidney, skeletal muscle } \\
\text { HOXL1 }\end{array}$ \\
& 15 & $2.4 \mathrm{~kb}$ & $574 \mathrm{AA}$ & $85 \%$ & Heart, lung, pancreas, spleen, skeletal \\
muscle
\end{tabular}

LOX: lysyl oxidase; LOXL: lysyl oxidase like protein; AA: amino acids.

also detected in the heart, uterus, testis, and ovary $[2,3]$ (Table 1).

LOX is initially synthesized as a $46 \mathrm{kDa}$ prozymogen by fibroblasts and myofibroblasts. Signal peptide shearing and N-terminal glycosylation convert the pro-zymogen into the $50 \mathrm{kDa} \mathrm{LOX}$ proenzyme, which is inactive or has limited activity $[2,3]$. The proenzyme then undergoes post-translational modifications in the endoplasmic reticulum and Golgi apparatus, and is transferred into extracellular spaces. Here, extracellular proteolytic enzymes shear the proenzyme at a Gly-Asp bond into two peptide segments of sizes 30 and $18 \mathrm{kDa}$, the mature LOX form and LOX-pp (LOX pro-peptide), respectively $[5,6]$.

\section{LOX BIOLOGICAL FUNCTION}

\section{Collagen crosslinking}

LOX can catalyze the oxidative deamination of lysine and hydroxylysine residues of certain non-helical telopeptide regions in collagen molecules to generate lysine- or hydroxylysine-aldehyde. Condensation reactions then spontaneously occur between the aldehydes and neighboring lysine or hydroxylysyl residues, producing divalent, crosslinked dehydro-hydroxylysinonorleucine (HLNL) and dehydro-dihydroxylysinonorleucine (DHLNL) $[2,7,8]$. DHLNL reacts with the third lysine or hydroxylysyl residue to generate mature crosslinked products, pyridinoline and/or deoxy-pyridinoline $[2,7,8]$. As this process continues, HLNL and DHLNL concentrations decrease, while that of pyridinolines and other mature products increase during early growth and development of the aorta [7]. At present, pyridinoline is used to detect mature collagen fibers $[2,7]$.

\section{Elastin crosslinking}

LOX oxidatively deaminates lysine residues in elastin to lysine-aldehydes. After a series of spontaneous condensation reactions, three reactive lysine-aldehydes and the fourth lysine residue form tetrafunctional desmosines, which are also used to measure mature elastin levels $[7,9]$.
The most important biological activity of LOX is catalyzing crosslinking of soluble collagen or elastin proteins in the ECM into insoluble mature fibers. This process is essential for ECM structural stability and integrity, and contributes to tissues tensile strength $[10,11]$.

\section{Tumorigenesis}

LOX/LOXL may promote or suppress tumorigenesis, depending on cell type, location, and transformation status $[12,13]$. LOX expression is enhanced in various tumors, including head and neck squamous cell carcinoma (HNSCC), and breast and colorectal cancers $[11,12]$, and is associated with poor disease-free and overall survival [10]. Factors that promote tumor development or progression, such as TNF- $\alpha$, TGF- $\beta$, or HIF-1, can upregulate LOX $[10,13]$. LOX also reportedly improved tumor cell proliferation and survival through focal adhesion kinase (FAK) activation, which subsequently upregulates fibronectin and provides a permissive niche to support metastasis [13].

LOXL2 remodels the tumor microenviroment, regulates cell adhesion, invasion, and motility, and improves tumor cell survival and chemoresistance [12]. LOXL2 overexpression was correlated with more aggressive breast cancer $[14,15]$, and primary gastric tumor invasion, lymph node metastasis, and reduced patient survival. LOXL2 may promote tumorigenesis and progression by activating Src/FAK signaling, which can be suppressed using a LOXL2 antibody [16].

LOXL4 is upregulated in HNSCC, likely via the transcription factors, TATA-box-binding protein (TBP) and SP1, which bind the LOXL4 promoter [17]. LOXL4 also promotes colorectal tumor metastasis and resistance to radiotherapy and chemotherapy $[12,18]$.

These studies suggest that LOX/LOXL promote cancer progression. However, LOX was initially described as a tumor suppressor, by inhibiting HRAS-mediated oncogenic transformation [12]. LOX downregulation has been observed in tumor tissues, and silencing LOX was associated with a more aggressive tumor phenotype and decreased patient survival [10]. This tumor suppressive activity is associated with $18 \mathrm{kDa}$ LOX-pp, which inhibited FGF-2 signaling in prostate cancer (PCa) 
[19], oncogenic bcl-2 activity in breast cancer [20], and nuclear factor $-\kappa \mathrm{B}(\mathrm{NF}-\kappa \mathrm{B})$ activation in lung and prostate carcinoma [10]. LOX-pp also promoted phenotypic reversion in ras-transformed NIH3T3 cells [21], and promoted apoptosis in PCa cells by blocking mitogenactivated protein kinase/extracellular signal-related kinase pathways [22] or inhibiting DNA repair [23].

\section{LOX REGULATION}

LOX is regulated at three levels: LOX precursor synthesis in myofibroblasts and fibroblasts, extracellular conversion to the mature enzyme, and direct regulation of enzymatic activity [2]. The many LOX regulators include promoters of dihydrotestosterone (DTH), growth differentiation factor-9 (GDF-9), Activen A [24], interleukin-4 (IL-4) [25], hypoxia inducible factor $1 \alpha$ (HIF-1 $\alpha$ ), advanced glycation end products-dependent transcription factor (AGE-DTF), transforming growth factor- $\beta$ (TGF- $\beta$ ), procollagen enzyme $C$ (PCP), tolloidlike protein 1 , fibronectin, aminopeptidase $\mathrm{B}$, and reactive oxygen species (ROS) [2, 26-28], as well as inhibitors of follicle-stimulating hormone (FSH) [24], prostaglandin $\mathrm{E}_{2}$ $\left(\mathrm{PGE}_{2}\right)$, and homocysteine $[2,29]$ (Figure 1).
The irreversible LOX inhibitor, $\beta$-aminopropionitrile (BAPN), is currently used in research both in vivo and in vitro $[7,30]$. However, lathyrism is a long-term side effect of BAPN, and includes bone deformities, joint dislocation, kyphoscoliosis, weakening of tendon and ligament attachments, weakening of skin and cartilage, hernia formation, and arterial aneurysm or dissection [30].

\section{LOX IN THE URINARY SYSTEM}

\section{Kidney}

LOX/LOXL2 overexpression in human clear cell renal cell carcinoma (ccRCC) $[31,32]$ promoted tumor cell migration and adhesion, as well as matrix stiffness to enhance tumor progression and metastasis [32]. LOXL2 overexpression was associated with higher ccRCC pathological stages, and upregulated integrins- $\alpha 5$ / $\beta 1$, which enhanced cancer cell survival, invasion, and metastasis via protease- and proteasome-dependent mechanisms [31]. Tumor suppressive microRNA-26a/b [33] and microRNA-29s [34] directly inhibited LOXL2 to reduce $\mathrm{RCC}$ cell migration and invasion. These findings suggest new strategies for treating ccRCC [32] (Table 2).

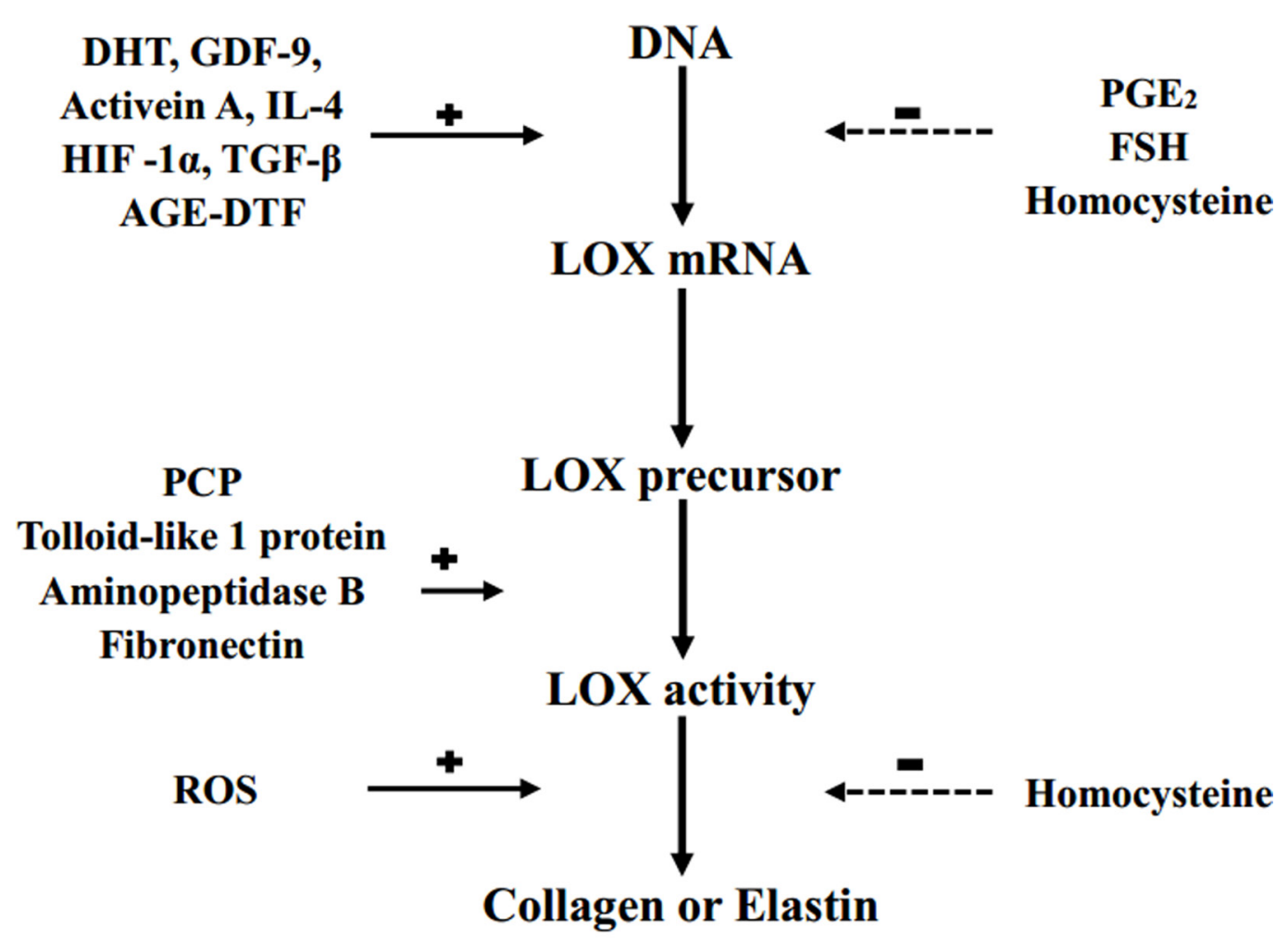

\section{Crosslinking}

Figure 1: LOX regulation. DHT: dihydrotestosterone; GDF-9: growth differentiation factor-9; IL-4: interleukin-4; HIF-1 $\alpha$ : hypoxia inducible factor $1 \alpha$; TGF- $\beta$ : transforming growth factor- $\beta$; AGE-DTF: advanced glycation end products-dependent transcription factor; PCP: procollagen enzyme C; ROS: reactive oxygen specie; PGE2: prostaglandin E2; FSH: follicle-stimulating hormone; +: stimulation; -: inhibition. 


\begin{tabular}{|c|c|c|c|}
\hline $\begin{array}{l}\text { Am J Pathol, } \\
2016,[32]\end{array}$ & Di Stefano V & $\begin{array}{l}\text { 1. LOX promoted ccRCC progression and metastasis by increasing } \\
\text { cellular migration, adhesion, stiffness of matrix increment. }\end{array}$ & $\begin{array}{l}\text { LOX } \\
\text { Promoter }\end{array}$ \\
\hline $\begin{array}{l}\text { Mol Cancer Res, } \\
\text { 2014, [31] }\end{array}$ & Hase H & $\begin{array}{l}\text { 1. LOXL } 2 \text { was correlated with ccRCC pathological stage. } \\
\text { 2. LOXL } 2 \text { promoted ccRCC progression by improving } \\
\text { integrins- } \alpha 5 / \beta 1 \text {. }\end{array}$ & $\begin{array}{l}\text { LOXL2 } \\
\text { Promoter }\end{array}$ \\
\hline $\begin{array}{l}\text { Int J Oncol, } \\
2016,[33]\end{array}$ & Kurozumi A & $\begin{array}{l}\text { 1. MicroRNA-26a/b inhibited LOXL2 to restrain ccRCC migration } \\
\text { and invasion. }\end{array}$ & $\begin{array}{l}\text { LOXL2 } \\
\text { Promoter }\end{array}$ \\
\hline $\begin{array}{l}\text { FEBS Lett, } \\
2015,[34]\end{array}$ & Nishikawa R & $\begin{array}{l}\text { 1. MicroRNA-29 inhibited LOXL2 to restrain ccRCC migration and } \\
\text { invasion. }\end{array}$ & $\begin{array}{l}\text { LOXL2 } \\
\text { Promoter }\end{array}$ \\
\hline \multicolumn{4}{|c|}{ Bladder carcinoma } \\
\hline $\begin{array}{l}\text { Oncotarget, } \\
2016,[41]\end{array}$ & Gross-Cohen M & $\begin{array}{l}\text { 1. Tumor suppressor of heparanase } 2 \text { is related to low cancer } \\
\text { grading and staging. } \\
\text { 2. Bladder carcinomas which exhibited strong Hpa } 2 \text { staining also } \\
\text { showed strong LOX staining }\end{array}$ & $\begin{array}{l}\text { LOX } \\
\text { Suppressor }\end{array}$ \\
\hline $\begin{array}{l}\text { Cancer Res, } \\
2007,[40]\end{array}$ & $\mathrm{Wu} \mathrm{G}$ & $\begin{array}{l}\text { 1. LOXL1/4 gene methylation and loss of expression was found in } \\
\text { primary bladder cancer. } \\
\text { 2. LOXL1/4 inhibited Ras/ERK pathway to exert suppress bladder } \\
\text { cancer. }\end{array}$ & $\begin{array}{l}\text { LOXL1/4 } \\
\text { Suppressor }\end{array}$ \\
\hline $\begin{array}{l}\text { Mol Cancer, } \\
2014,[42]\end{array}$ & Deng $\mathrm{H}$ & $\begin{array}{l}\text { 1. MicroRNA-193a-3p promote bladder cancer chemoresistance via } \\
\text { repressing LOXL4 expression. }\end{array}$ & $\begin{array}{l}\text { LOXL4 } \\
\text { Suppressor }\end{array}$ \\
\hline \multicolumn{4}{|c|}{ Prostate cancer (PCa) } \\
\hline $\begin{array}{l}\text { Oncol Lett, } \\
2016,[46]\end{array}$ & Zheng W & $\begin{array}{l}\text { 1. LOX status was higher in low-grade PCa than high-grade tissue. } \\
\text { 2. Decreased LOX level increased risk of tumor associated } \\
\text { mortality. }\end{array}$ & $\begin{array}{l}\text { LOX } \\
\text { Suppressor }\end{array}$ \\
\hline $\begin{array}{l}\text { Cancer Res, } \\
1998,[47]\end{array}$ & Ren C & $\begin{array}{l}\text { 1. LOX mRNA was decreased in metastatic tumor than primary } \\
\text { prostate tumor. } \\
\text { 2. LOX expression decreased during progression of metastasis }\end{array}$ & $\begin{array}{l}\text { LOX } \\
\text { Suppressor }\end{array}$ \\
\hline $\begin{array}{l}\text { PLoS One, } \\
2015,[48]\end{array}$ & Nilsson M & $\begin{array}{l}\text { 1. High LOX expression in tumor adjacent non-malignant prostate } \\
\text { epithelium were associated with shorter cancer specific survival. } \\
\text { 2. Strong LOX level in prostate tumor epithelium was correlated to } \\
\text { higher Gleason score and metastases. }\end{array}$ & $\begin{array}{l}\text { LOX } \\
\text { Promoter }\end{array}$ \\
\hline $\begin{array}{l}\text { Sci Rep, 2016, } \\
\text { [49] }\end{array}$ & Nilsson M & $\begin{array}{l}\text { 1. Administration of BAPN, inhibitor of LOX, before AT-1 cells } \\
\text { implantation suppressed PCa growth. }\end{array}$ & $\begin{array}{l}\text { LOX } \\
\text { Promoter }\end{array}$ \\
\hline $\begin{array}{l}\text { J Hum Genet, } \\
2017,[50]\end{array}$ & Kato M & $\begin{array}{l}\text { 1. LOXL2 was overexpressed in PCa region. } \\
\text { 2. LOXL2 knockdown inhibited PCa migration and invasion. }\end{array}$ & $\begin{array}{l}\text { LOXL2 } \\
\text { Promoter }\end{array}$ \\
\hline $\begin{array}{l}\text { Oncogene, } \\
2009,[19]\end{array}$ & $\begin{array}{l}\text { Palamakumbura } \\
\text { AH }\end{array}$ & $\begin{array}{l}\text { 1. LOX-pp inhibited DNA synthesis, ERK } 1 / 2, \text { AKT and FRS- } 2 \alpha \text { to } \\
\text { suppress proliferation of PCa. }\end{array}$ & $\begin{array}{l}\text { LOX-pp } \\
\text { Suppressor }\end{array}$ \\
\hline $\begin{array}{l}\text { Oncogene, } \\
2015,[23]\end{array}$ & Bais MV & $\begin{array}{l}\text { 1. LOX-pp induce nuclear DNA repair foci to make PCa sensitive to } \\
\text { radiation effect. }\end{array}$ & $\begin{array}{l}\text { LOX-pp } \\
\text { Suppressor }\end{array}$ \\
\hline $\begin{array}{l}\text { J Cell Commun } \\
\text { Signal, 2016, [52] }\end{array}$ & Alsulaiman M & $\begin{array}{l}\text { 1. rLOX-pp inhibit OPG but enhance CCN2 expression to stimulate } \\
\text { osteoclast fusion }\end{array}$ & $\begin{array}{c}\text { LOX-pp } \\
\text { Suppressor }\end{array}$ \\
\hline
\end{tabular}

Mild atrophy and varying degrees of fibrosis have been observed in the tubulointerstitial tissues of spontaneously hypertensive rats, with $\mathrm{TGF}-\alpha / \beta$ upregulation and LOX downregulation in the renal cortex compared to control rats with normal blood pressure.
High dose perindopril could reduce hypertensive renal injury by antagonizing mineralocorticoid to prevent LOX downregulation [35]. However, both TGF- $\beta 1$ and LOX were overexpressed in the tubular epithelial cells of a hereditary nephritis mouse model with chronic 
renal fibrosis. Elevated LOX can catalyze interstitial collagen crosslinking to induce irreversible chronic renal tubulointerstitial fibrosis in kidney [36]. Adriamycin toxicity may also be the result of LOX upregulation leading to this irreversible progression [37]. Similarly, hyperuricemia-induced LOX upregulation can increase fibronectin synthesis in tubular epithelial cells and promote renal fibrosis, and LOX knockdown via siRNA reduces this effect [38]. Additionally, transplanted renal parenchyma exhibiting delayed graft failure after 6-12 months showed increased LOX activity, which could induce ischemia, renovascular hypertension, renal dysfunction, and failure [39].

\section{Bladder}

LOXL1/4 gene methylation and loss of expression is commonly observed in primary bladder cancer cells, and LOXL1/4 reintroduction into these cells can reduce colony formation. LOXL1/4 might suppress cancer cell growth by blocking Ras/ERK signaling [40]. The tumor suppressor, heparanase 2 (Hpa2), attenuates bladder carcinoma and is associated with lower tumor grading and staging. Cells with high Hpa2 expression also overexpress LOX. By enhancing LOX expression, Hpa2 might reduce Erk phosphorylation to suppress bladder tumor growth [41]. Additionally, microRNA (miR)-193a-3p modulates oxidative stress (OS) signaling to promote multi-drug chemoresistance in bladder cancer by inhibiting LOXL4 expression. The miR-193a-3p/LOXL4/OS axis may be a new target for anti-bladder cancer chemotherapeutics [42] (Table 2).

Menkes disease (MD), an infantile-onset X-linked recessive neurodegenerative disorder, is characterized by copper $(\mathrm{Cu})$ metabolism deficiency or dysfunction [43]. LOX enzymatic activity, which is essential for collagen or elastin crosslinking, can be affected by copper transport alterations. LOX deficiency-related connective tissue defects are accompanied by a high frequency of bladder diverticula (38.6\% of total patients) [43]. Moreover, tissue inflammation was noted in a bladder outlet obstruction (BOO) model, with elevated LOX expression in lamina propria and increased collagen secretion in isolated urothelial cells [44]. Hypoxia was also triggered in partial BOO rats. While 2-methoxyestradiol reduced HIF-1 $\alpha$ expression in these rats, LOX, downstream of HIF-1 $\alpha$, was substantially elevated. This suggests the presence of additional hypoxia or inflammatory stimuli that can induce LOX overexpression [45].

\section{Prostate}

LOX expression is lower in $\mathrm{PCa}$ tissues than in benign prostate hyperplasia (BPH) nodules [46], and is also reduced in metastases compared with primary $\mathrm{PCa}$ tissues, suggesting LOX decline during progression to metastasis [47]. Lower LOX level was associated with higher PCa grade and increased risk of tumor-associated mortality [46]. These findings suggest that LOX acts as a tumor suppressor in PCa.

On the contrary, another group found that high LOX expression in adjacent non-malignant prostate epithelium was associated with shorter cancer-specific survival, and LOX overexpression in tumor epithelium was related to higher Gleason score and metastasis [48]. Administration of the LOX inhibitor, BAPN, before AT-1 cell implantation suppressed $\mathrm{PCa}$ growth in an animal model, while treatment started after tumor implantation had no effect, or even increased cell growth [49]. Thus, LOX function appears context-dependent, exhibiting both tumor promoting and suppressing properties in $\mathrm{PCa}$ [49]. Further studies are needed to clarify the circumstances under which LOX inhibitors could be adapted as anti-PCa therapeutics.

Knockdown of highly expressed LOXL2 in PCa can reduce tumor cell invasion and migration [50].

Meanwhile, LOX-pp appears to act as a tumor suppressor in lung, breast, pancreas, and gastrointestinal system cancers [51-53]. In PCa, elevated autocrine fibroblast growth factor 2 (FGF-2) promotes tumor cell growth by stimulating DNA synthesis, ERK1/2, AKT and FRS-2 $\alpha$ (fibroblast growth factor receptor substrate-2). However, LOX-pp blocks these pathways to reduce cell proliferation (DU 145), suggesting LOX-pp targeting of the FGF receptor [19]. Recombinant LOXpp (rLOX-pp) induced nuclear DNA repair, increasing PCa cell sensitivity to ionizing radiation [23]. rLOXpp also decreased osteoprotegerin (OPG) and increased CCN2 expression in bone marrow-derived cells to improve osteoblast differentiation, which was inhibited by PCa cell-conditioned media [52]. Thus, simultaneous administration of recombinant LOX-pp and LOX inhibitors may be a promising anti-cancer treatment option $[10,47]$. Further research addressing the contrasting roles of mature LOX/LOXL and LOX-pp in cancer progression, and a better understanding of LOX-associated signaling in tumorigenesis will be required for the success of such therapeutics $[10,47]$ (Table 2).

\section{Testis}

One study showed that LOXL1 plays a subtle and likely multifactorial role in male fertility and sexual development [54]. High LOXL3/4 was observed in human testis, although their exact roles are presently unknown $[55,56]$.

\section{Other}

LOX expression was low, and collagen fiber arrangements were loose and disorganized in the pelvic floor ligaments of female patients with stress urinary incontinence [57]. LOX downregulation can decrease collagen crosslinking and increase the susceptibility of 
immature collagen to degradation, which may reduce pelvic floor ligament tensile strength or elasticity [57]. However, reduced ECM synthesis, increased proteolysis, and LOX overexpression were observed in urethral cells from a rat stress urinary incontinence model after vaginal trauma [58]. Trauma can elevate LOX expression, which may explain this discrepancy

Female pelvic floor dysfunction is closely associated with elastin stability [59]. Normal elastin crosslinking in the urogenital tract was hampered in LOXL1 knockout mice, which had higher frequencies of pelvic organ prolapse (POP) [59] and lower urinary tract dysfunction (LUTS), as well as lower mean bladder capacities and voiding pressures [60]. In these mice, POP incidence was more frequent in spontaneous than cesarean delivery models, with higher bladder contraction frequencies and more disorganized elastic fibers in the vagina and urethra [61]. However, further investigation is needed to characterize underlying mechanisms.

Overexpressed LOX may also promote nephrolithiasis [62]. Additionally, our previous work showed that LOX accelerated corpus cavernosum fibrosis in an ischemic priapism rat model, while BAPN reversed the fibrotic process [63].

\section{CONCLUSIONS}

LOX family members induce varying effects, including tumor promotion and inhibition, in different urological organs. While normal LOX/LOXL expression is crucial for female pelvic floor function, LOX/LOXL inhibitors might reverse kidney fibrosis and ischemic priapism. Further investigation is necessary to clarify the specific functions of LOX/LOXL in tumorigenesis and progression.

\section{ACKNOWLEDGMENTS} services.

We thank "English Edit OT" for their revision

\section{CONFLICTS OF INTEREST}

The authors declare that they have no conflicts of interest.

\section{GRANT SUPPORT}

This study was supported by the Natural Science Foundation of China (No. 81671453 and 81270691).

\section{REFERENCES}

1. Asuncion L, Fogelgren B, Fong KS, Fong SF, Kim Y, Csiszar K. A novel human lysyl oxidase-like gene (LOXL4) on chromosome 10q24 has an altered scavenger receptor cysteine rich domain. Matrix Biol. 2001; 20:487-91.

2. López B. Role of lysyl oxidase in myocardial fibrosis: from basic science to clinical aspects. Am J Physiol Heart Circ Physiol. 2010; 299:H1-9. https://doi.org/10.1152/ ajpheart.00335.2010.-Because.

3. Hornstra IK, Birge S, Starcher B, Bailey AJ, Mecham RP, Shapiro SD. Lysyl oxidase is required for vascular and diaphragmatic development in mice. J Biol Chem. 2003; 278:14387-93. https://doi.org/10.1074/jbc.M210144200.

4. Jourdan-Le Saux C, Tomsche A, Ujfalusi A, Jia L, Csiszar K. Central nervous system, uterus, heart, and leukocyte expression of the LOXL3 gene, encoding a novel lysyl oxidase-like protein. Genomics. 2001; 74:211-8. https:// doi.org/10.1006/geno.2001.6545.

5. Lucero HA, Kagan HM. Lysyl oxidase: an oxidative enzyme and effector of cell function. Cell Mol Life Sci. 2006; 63:2304-16. https://doi.org/10.1007/s00018-006-6149-9.

6. Papadantonakis N, Matsuura S, Ravid K. Megakaryocyte pathology and bone marrow fibrosis: the lysyl oxidase connection. Blood. 2012; 120:1774-81. https://doi. org/10.1182/blood-2012-02-402594.

7. Bruel A, Ortoft G, Oxlund H. Inhibition of cross-links in collagen is associated with reduced stiffness of the aorta in young rats. Atherosclerosis. 1998; 140:135-45.

8. Eyre DR, Oguchi H. The hydroxypyridinium crosslinks of skeletal collagens: their measurement, properties and a proposed pathway of formation. Biochem Biophys Res Commun. 1980; 92:403-10.

9. Kagan HM. Intra- and extracellular enzymes of collagen biosynthesis as biological and chemical targets in the control of fibrosis. Acta Trop. 2000; 77:147-52.

10. Cox TR, Erler JT. Lysyl oxidase in colorectal cancer. Am J Physiol Gastrointest Liver Physiol. 2013; 305:G659-66. https://doi.org/10.1152/ajpgi.00425.2012.

11. Cox TR, Gartland A, Erler JT. Lysyl Oxidase, a Targetable Secreted Molecule Involved in Cancer Metastasis. Cancer Res. 2016; 76:188-92. https://doi.org/10.1158/0008-5472. CAN-15-2306.

12. Barker HE, Cox TR, Erler JT. The rationale for targeting the LOX family in cancer. Nat Rev Cancer. 2012; 12:540-52. https://doi.org/10.1038/nrc3319.

13. Erler JT, Bennewith KL, Nicolau M, Dornhofer N, Kong C, Le QT, Chi JT, Jeffrey SS, Giaccia AJ. Lysyl oxidase is essential for hypoxia-induced metastasis. Nature. 2006; 440:1222-6. https://doi.org/10.1038/nature04695.

14. Barker HE, Chang J, Cox TR, Lang G, Bird D, Nicolau M, Evans HR, Gartland A, Erler JT. LOXL2-mediated matrix remodeling in metastasis and mammary gland involution. Cancer Res. 2011; 71:1561-72. https://doi. org/10.1158/0008-5472.CAN-10-2868.

15. Moreno-Bueno G, Salvador F, Martin A, Floristan A, Cuevas EP, Santos V, Montes A, Morales S, Castilla MA, RojoSebastian A, Martinez A, Hardisson D, Csiszar K, et al. 
Lysyl oxidase-like 2 (LOXL2), a new regulator of cell polarity required for metastatic dissemination of basallike breast carcinomas. EMBO Mol Med. 2011; 3:528-44. https://doi.org/10.1002/emmm.201100156.

16. Peng L, Ran YL, Hu H, Yu L, Liu Q, Zhou Z, Sun YM, Sun LC, Pan J, Sun LX, Zhao P, Yang ZH. Secreted LOXL2 is a novel therapeutic target that promotes gastric cancer metastasis via the Src/FAK pathway. Carcinogenesis. 2009; 30:1660-9. https://doi.org/10.1093/carcin/bgp178.

17. Gorogh T, Holtmeier C, Weise JB, Hoffmann M, Ambrosch P, Laudien M, Csiszar K. Functional analysis of the $5^{\prime}$ flanking domain of the LOXL4 gene in head and neck squamous cell carcinoma cells. Int J Oncol. 2008; 33:1091-8.

18. Kim Y, Roh S, Park JY, Kim Y, Cho DH, Kim JC. Differential expression of the LOX family genes in human colorectal adenocarcinomas. Oncol Rep. 2009; 22:799-804.

19. Palamakumbura AH, Vora SR, Nugent MA, Kirsch KH, Sonenshein GE, Trackman PC. Lysyl oxidase propeptide inhibits prostate cancer cell growth by mechanisms that target FGF-2-cell binding and signaling. Oncogene. 2009; 28:3390-400. https://doi.org/10.1038/onc.2009.203.

20. Wu M, Min C, Wang X, Yu Z, Kirsch KH, Trackman PC, Sonenshein GE. Repression of BCL2 by the tumor suppressor activity of the lysyl oxidase propeptide inhibits transformed phenotype of lung and pancreatic cancer cells. Cancer Res. 2007; 67:6278-85. https://doi. org/10.1158/0008-5472.CAN-07-0776.

21. Palamakumbura AH, Jeay S, Guo Y, Pischon N, Sommer P, Sonenshein GE, Trackman PC. The propeptide domain of lysyl oxidase induces phenotypic reversion of rastransformed cells. J Biol Chem. 2004; 279:40593-600. https://doi.org/10.1074/jbc.M406639200.

22. Bais MV, Nugent MA, Stephens DN, Sume SS, Kirsch KH, Sonenshein GE, Trackman PC. Recombinant lysyl oxidase propeptide protein inhibits growth and promotes apoptosis of pre-existing murine breast cancer xenografts. PLoS One. 2012; 7:e31188. https://doi.org/10.1371/journal. pone.0031188.

23. Bais MV, Ozdener GB, Sonenshein GE, Trackman PC. Effects of tumor-suppressor lysyl oxidase propeptide on prostate cancer xenograft growth and its direct interactions with DNA repair pathways. Oncogene. 2015; 34:1928-37. https://doi.org/10.1038/onc.2014.147.

24. Harlow CR, Rae M, Davidson L, Trackman PC, Hillier SG. Lysyl oxidase gene expression and enzyme activity in the rat ovary: regulation by follicle-stimulating hormone, androgen, and transforming growth factor-beta superfamily members in vitro. Endocrinology. 2003; 144:154-62. https://doi.org/10.1210/en.2002-220652.

25. Papacleovoulou G, Critchley HO, Hillier SG, Mason JI. IL1alpha and IL4 signalling in human ovarian surface epithelial cells. J Endocrinol. 2011; 211:273-83. https://doi. org/10.1530/JOE-11-0081.

26. Rosenbloom J, Ren S, Macarak E. New frontiers in fibrotic disease therapies: The focus of the Joan and Joel
Rosenbloom Center for Fibrotic Diseases at Thomas Jefferson University. Matrix Biol. 2016; 51:14-25. https:// doi.org/10.1016/j.matbio.2016.01.011.

27. Halberg N, Khan T, Trujillo ME, Wernstedt-Asterholm I, Attie AD, Sherwani S, Wang ZV, Landskroner-Eiger S, Dineen S, Magalang UJ, Brekken RA, Scherer PE. Hypoxia-inducible factor 1alpha induces fibrosis and insulin resistance in white adipose tissue. Mol Cell Biol. 2009; 29:4467-83. https://doi.org/10.1128/mcb.00192-09.

28. Higgins DF, Kimura K, Bernhardt WM, Shrimanker N, Akai Y, Hohenstein B, Saito Y, Johnson RS, Kretzler M, Cohen CD, Eckardt KU, Iwano M, Haase VH. Hypoxia promotes fibrogenesis in vivo via HIF-1 stimulation of epithelial-tomesenchymal transition. J Clin Invest. 2007; 117:3810-20. https://doi.org/10.1172/JCI30487.

29. Thaler R, Agsten M, Spitzer S, Paschalis EP, Karlic H, Klaushofer K, Varga F. Homocysteine suppresses the expression of the collagen cross-linker lysyl oxidase involving IL-6, Fli1, and epigenetic DNA methylation. J Biol Chem. 2011; 286:5578-88. https://doi.org/10.1074/ jbc.M110.166181.

30. Maki JM. Inactivation of the Lysyl Oxidase Gene Lox Leads to Aortic Aneurysms, Cardiovascular Dysfunction, and Perinatal Death in Mice. Circulation. 2002; 106:2503-9. https://doi.org/10.1161/01.cir.0000038109.84500.1e.

31. Hase H, Jingushi K, Ueda Y, Kitae K, Egawa H, Ohshio I, Kawakami R, Kashiwagi Y, Tsukada Y, Kobayashi T, Nakata W, Fujita K, Uemura M, et al. LOXL2 status correlates with tumor stage and regulates integrin levels to promote tumor progression in ccRCC. Mol Cancer Res. 2014; 12:1807-17. https://doi.org/10.1158/1541-7786. mcr-14-0233.

32. Di Stefano V, Torsello B, Bianchi C, Cifola I, Mangano E, Bovo G, Cassina V, De Marco S, Corti R, Meregalli C, Bombelli S, Vigano P, Battaglia C, et al. Major Action of Endogenous Lysyl Oxidase in Clear Cell Renal Cell Carcinoma Progression and Collagen Stiffness Revealed by Primary Cell Cultures. Am J Pathol. 2016; 186:2473-85. https://doi.org/10.1016/j.ajpath.2016.05.019.

33. Kurozumi A, Kato M, Goto Y, Matsushita R, Nishikawa R, Okato A, Fukumoto I, Ichikawa T, Seki N. Regulation of the collagen cross-linking enzymes LOXL2 and PLOD2 by tumor-suppressive microRNA-26a/b in renal cell carcinoma. Int J Oncol. 2016; 48:1837-46. https://doi. org/10.3892/ijo.2016.3440.

34. Nishikawa R, Chiyomaru T, Enokida H, Inoguchi S, Ishihara T, Matsushita R, Goto Y, Fukumoto I, Nakagawa M, Seki N. Tumour-suppressive microRNA-29s directly regulate LOXL2 expression and inhibit cancer cell migration and invasion in renal cell carcinoma. FEBS Lett. 2015; 589:2136-45. https://doi.org/10.1016/j.febslet.2015.06.005.

35. Miana M, de Las Heras N, Rodriguez C, Sanz-Rosa D, Martin-Fernandez B, Mezzano S, Lahera V, MartinezGonzalez J, Cachofeiro V. Effect of eplerenone on hypertension-associated renal damage in rats: potential 
role of peroxisome proliferator activated receptor gamma (PPAR-gamma). J Physiol Pharmacol. 2011; 62:87-94.

36. Goto Y, Uchio-Yamada K, Anan S, Yamamoto Y, Ogura A, Manabe N. Transforming growth factor-betal mediated up-regulation of lysyl oxidase in the kidneys of hereditary nephrotic mouse with chronic renal fibrosis. Virchows Arch. 2005; 447:859-68. https://doi.org/10.1007/ s00428-005-0001-8.

37. Di Donato A, Ghiggeri GM, Di Duca M, Jivotenko E, Acinni R, Campolo J, Ginevri F, Gusmano R. Lysyl oxidase expression and collagen cross-linking during chronic adriamycin nephropathy. Nephron. 1997; 76:192-200.

38. Yang Z, Xiaohua W, Lei J, Ruoyun T, Mingxia X, Weichun H, Li F, Ping W, Junwei Y. Uric acid increases fibronectin synthesis through upregulation of lysyl oxidase expression in rat renal tubular epithelial cells. Am J Physiol Renal Physiol. 2010; 299:F336-46. https://doi.org/10.1152/ ajprenal.00053.2010.

39. Chen Z, Li Y, Xu H. Elevated ischaemia-associated lysyl oxidase activity in delayed graft failure 6-12 months after renal transplantation. Exp Physiol. 2017; 102:282-7. https:// doi.org/10.1113/ep085444.

40. Wu G, Guo Z, Chang X, Kim MS, Nagpal JK, Liu J, Maki JM, Kivirikko KI, Ethier SP, Trink B, Sidransky D. LOXL1 and LOXL4 are epigenetically silenced and can inhibit ras/ extracellular signal-regulated kinase signaling pathway in human bladder cancer. Cancer Res. 2007; 67:4123-9. https://doi.org/10.1158/0008-5472.can-07-0012.

41. Gross-Cohen M, Feld S, Naroditsky I, Nativ O, Ilan N, Vlodavsky I. Heparanase 2 expression inversely correlates with bladder carcinoma grade and stage. Oncotarget. 2016; 7:22556-65. https://doi.org/10.18632/oncotarget.8003.

42. Deng H, Lv L, Li Y, Zhang C, Meng F, Pu Y, Xiao J, Qian L, Zhao W, Liu Q, Zhang D, Wang Y, Zhang H, et al. miR$193 a-3 p$ regulates the multi-drug resistance of bladder cancer by targeting the LOXL4 gene and the oxidative stress pathway. Mol Cancer. 2014; 13:234. https://doi. org/10.1186/1476-4598-13-234.

43. Cosimo QC, Daniela L, Elsa B, Carlo DV, Giuseppe F. Kinky hair, kinky vessels, and bladder diverticula in Menkes disease. J Neuroimaging. 2011; 21:e114-6. https:// doi.org/10.1111/j.1552-6569.2010.00476.x.

44. Hughes FM Jr, Sexton SJ, Jin H, Govada V, Purves JT. Bladder fibrosis during outlet obstruction is triggered through the NLRP3 inflammasome and the production of IL-1beta. Am J Physiol Renal Physiol. 2017; 313:F603-F610. https:// doi.org/10.1002/cam4.110910.1152/ajprenal.00128.2017.

45. Drzewiecki BA, Anumanthan G, Penn HA, Tanaka ST, Thomas JC, Adams MC, Brock JW 3rd, Pope JC, Matusik RJ, Hayward S, Clayton DB. Modulation of the hypoxic response following partial bladder outlet obstruction. J Urol. 2012; 188:1549-54. https://doi.org/10.1016/j. juro.2012.02.037.
46. Zheng W, Wang X, Chen Q, Fang K, Wang L, Chen F, Li X, Li Z, Wang J, Liu Y, Yang D, Song X. Low extracellular lysyl oxidase expression is associated with poor prognosis in patients with prostate cancer. Oncol Lett. 2016; 12:3161-6. https://doi.org/10.3892/ol.2016.5118.

47. Ren C, Yang G, Timme TL, Wheeler TM, Thompson TC. Reduced lysyl oxidase messenger RNA levels in experimental and human prostate cancer. Cancer Res. 1998; 58:1285-90.

48. Nilsson M, Hagglof C, Hammarsten P, Thysell E, Stattin P, Egevad L, Granfors T, Jernberg E, Wikstrom P, Halin Bergstrom S, Bergh A. High Lysyl Oxidase (LOX) in the Non-Malignant Prostate Epithelium Predicts a Poor Outcome in Prostate Cancer Patient Managed by Watchful Waiting. PLoS One. 2015; 10:e0140985. https://doi. org/10.1371/journal.pone.0140985.

49. Nilsson M, Adamo H, Bergh A, Halin Bergstrom S. Inhibition of Lysyl Oxidase and Lysyl Oxidase-Like Enzymes Has Tumour-Promoting and Tumour-Suppressing Roles in Experimental Prostate Cancer. Sci Rep. 2016; 6:19608. https://doi.org/10.1038/srep19608.

50. Kato M, Kurozumi A, Goto Y, Matsushita R, Okato A, Nishikawa R, Fukumoto I, Koshizuka K, Ichikawa T, Seki N. Regulation of metastasis-promoting LOXL2 gene expression by antitumor microRNAs in prostate cancer. J Hum Genet. 2017; 62:123-32. https://doi.org/10.1038/ jhg.2016.68.

51. Zheng Y, Wang X, Wang H, Yan W, Zhang Q, Chang X. Expression of the lysyl oxidase propeptide in hepatocellular carcinoma and its clinical relevance. Oncol Rep. 2014; 31:1669-76. https://doi.org/10.3892/or.2014.3044.

52. Alsulaiman M, Bais MV, Trackman PC. Lysyl oxidase propeptide stimulates osteoblast and osteoclast differentiation and enhances PC3 and DU145 prostate cancer cell effects on bone in vivo. J Cell Commun Signal. 2016; 10:17-31. https://doi.org/10.1007/ s12079-015-0311-9.

53. Min C, Zhao Y, Romagnoli M, Trackman PC, Sonenshein GE, Kirsch KH. Lysyl oxidase propeptide sensitizes pancreatic and breast cancer cells to doxorubicin-induced apoptosis. J Cell Biochem. 2010; 111:1160-8. https://doi. org/10.1002/jcb.22828.

54. Wood HM, Lee UJ, Vurbic D, Sabanegh E, Ross JH, Li T, Damaser MS. Sexual development and fertility of Loxl1-/- male mice. J Androl. 2009; 30:452-9. https://doi. org/10.2164/jandrol.108.006122.

55. Huang Y, Dai J, Tang R, Zhao W, Zhou Z, Wang W, Ying $\mathrm{K}$, Xie Y, Mao Y. Cloning and characterization of a human lysyl oxidase-like 3 gene (hLOXL3). Matrix Biol. 2001; 20:153-7.

56. Maki JM, Tikkanen H, Kivirikko KI. Cloning and characterization of a fifth human lysyl oxidase isoenzyme: the third member of the lysyl oxidase-related subfamily 
with four scavenger receptor cysteine-rich domains. Matrix Biol. 2001; 20:493-6.

57. Kobak W, Lu J, Hardart A, Zhang C, Stanczyk FZ, Felix JC. Expression of lysyl oxidase and transforming growth factor beta2 in women with severe pelvic organ prolapse. J Reprod Med. 2005; 50:827-31.

58. Chen HY, Lin YN, Chen YH, Chen WC. Stress urinary incontinence following vaginal trauma involves remodeling of urethral connective tissue in female mice. Eur J Obstet Gynecol Reprod Biol. 2012; 163:224-9. https://doi. org/10.1016/j.ejogrb.2012.04.012.

59. Lee UJ, Gustilo-Ashby AM, Daneshgari F, Kuang M, Vurbic D, Lin DL, Flask CA, Li T, Damaser MS. Lower urogenital tract anatomical and functional phenotype in lysyl oxidase like-1 knockout mice resembles female pelvic floor dysfunction in humans. Am J Physiol Renal Physiol. 2008; 295:F545-55. https://doi.org/10.1152/ ajprenal.00063.2008.

60. Liu G, Daneshgari F, Li M, Lin D, Lee U, Li T, Damaser MS. Bladder and urethral function in pelvic organ prolapsed lysyl oxidase like-1 knockout mice. BJU Int. 2007; 100:414 8. https://doi.org/10.1111/j.1464-410X.2007.06929.x.

61. Gustilo-Ashby AM, Lee U, Vurbic D, Sypert D, Kuang M, Daneshgari F, Barber MD, Damaser MS. The impact of cesarean delivery on pelvic floor dysfunction in lysyl oxidase like-1 knockout mice. Female Pelvic Med Reconstr Surg. 2010; 16:21-30. https://doi.org/10.1097/ SPV.0b013e3181d00035.

62. Wang L, Raikwar N, Deng L, Yang M, Liang L, Shao C, Evan AP, Stambrook PJ, Sahota A, Tischfield JA. Altered gene expression in kidneys of mice with 2,8-dihydroxyadenine nephrolithiasis. Kidney Int. 2000; 58:528-36. https://doi. org/10.1046/j.1523-1755.2000.00199.x.

63. Gao L, Wu C, Fu F, You X, Ma X, Qin F, Li T, Wang R, Yuan J. Effect of lysyl oxidase (LOX) on corpus cavernous fibrosis caused by ischaemic priapism. J Cell Mol Med. 2018; 22:2018-22. https://doi.org/10.1111/jcmm.13411. 